Article

\title{
Improving Encapsulation of Hydrophilic Chloroquine Diphosphate into Biodegradable Nanoparticles: A Promising Approach against Herpes Virus Simplex-1 Infection
}

\author{
Tábata Loíse Cunha Lima ${ }^{1,2,+}$, Renata de Carvalho Feitosa ${ }^{1,+(\mathbb{D})}$, Emanuell dos Santos-Silva ${ }^{1}(\mathbb{D}$, \\ Alaine Maria dos Santos-Silva ${ }^{1}$ (D), Emerson Michell da Silva Siqueira ${ }^{3}$, \\ Paula Renata Lima Machado ${ }^{4}$, Alianda Maira Cornélio ${ }^{5}$, Eryvaldo Sócrates Tabosa do Egito ${ }^{2}$ (D), \\ Matheus de Freitas Fernandes-Pedrosa ${ }^{1}$ (D), Kleber Juvenal Silva Farias ${ }^{4, *}$ and \\ Arnóbio Antônio da Silva-Júnior 1,2,3,*(D)
}

1 Laboratory of Pharmaceutical Technology and Biotechnology, Department of Pharmacy, Federal University of Rio Grande do Norte, UFRN, Gal. Gustavo Cordeiro de Farias, Petrópolis, Natal 59.072-570, Brazil; tabata.cunhalima@gmail.com (T.L.C.L.); rcarvalhofeitosa@gmail.com (R.d.C.F.); emanuell14@gmail.com (E.d.S.-S.); alainemaria@ufrn.edu.br (A.M.d.S.-S.); mffpedrosa@gmail.com (M.d.F.F.-P.)

2 Graduate Program in Health Sciences, Federal University of Rio Grande do Norte (UFRN), Natal 59.072-570, Brazil; socratesegito@gmail.com

3 Graduate Program in Development and Technological Innovation in Medicines, Federal University of Rio Grande do Norte (UFRN), Natal 59.072-570, Brazil; siqueira.emerson.emss@gmail.com

4 Department of Clinical Analysis and Toxicology, Federal University of Rio Grande do Norte, UFRN, Gal. Gustavo Cordeiro de Farias, Petrópolis, Natal 59.072-570, Brazil; paulamachado@ufrnet.br

5 Department of Morphology, Federal University of Rio Grande do Norte, UFRN, Natal 59.072-570, Brazil; aliandamaira@gmail.com

* $\quad$ Correspondence: kleber.farias@ufcg.edu.br (K.J.S.F.); arnobiosilva@pq.cnpq.br (A.A.d.S.-J.); Tel.: +55-084-3342-9820 (A.A.d.S.-J.); Fax: +55-084-3342-9833 (A.A.d.S.-J.)

+ These authors have the same contribution in this manuscript.

Received: 28 September 2018; Accepted: 29 October 2018; Published: 3 December 2018

\begin{abstract}
Chloroquine diphosphate (CQ) is a hydrophilic drug with low entrapment efficiency in hydrophobic nanoparticles (NP). Herpes simplex virus type 1 (HSV-1) is an enveloped double-stranded DNA virus worldwide known as a common human pathogen. This study aims to develop chloroquine-loaded poly(lactic acid) (PLA) nanoparticles (CQ-NP) to improve the chloroquine anti- HSV-1 efficacy. CQ-NP were successfully prepared using a modified emulsification-solvent evaporation method. Physicochemical properties of the NP were monitored using dynamic light scattering, atomic force microscopy, drug loading efficiency, and drug release studies. Spherical nanoparticles were produced with modal diameter of $<300 \mathrm{~nm}$, zeta potential of $-20 \mathrm{mv}$ and encapsulation efficiency of $64.1 \%$. In vitro assays of CQ-NP performed in Vero E6 cells, using the MTT-assay, revealed different cytotoxicity levels. Blank nanoparticles (B-NP) were biocompatible. Finally, the antiviral activity tested by the plaque reduction assay revealed greater efficacy for CQ-NP compared to CQ at concentrations equal to or lower than $20 \mu \mathrm{g} \mathrm{mL}^{-1}(p<0.001)$. On the other hand, the B-NP had no antiviral activity. The CQ-NP has shown feasible properties and great potential to improve the antiviral activity of drugs.
\end{abstract}

Keywords: nanoparticles; poly(lactic acid); chloroquine; antiviral activity; herpes simplex; biological barriers 


\section{Introduction}

Herpes simplex virus type 1 (HSV-1) is an enveloped double-stranded DNA virus belonging to the Herpesviridae family. This virus, a common human pathogen, is the main cause of oral infection, affecting the mouth and lips. In addition, HSV-1 can be the infectious agent of several diseases including recurrent cold sores, keratoconjunctivitis, and life-threatening herpes encephalitis [1-3]. Following primary infection, HSV establishes infections in the neurons of the sensory ganglia from where it may become latent in the body [4,5]. In the nervous system, the virus is protected from the host immune system as a latent state, which can be reactivated by several factors, such as hormonal changes, ultraviolet (UV) light, and mainly the stress [6]. The treatment of infection caused by the HSV-1 include the use of drugs, such as acyclovir, valacyclovir, famciclovir, penciclovir, and cidofovirare [7]. Some pharmacokinetic limitations of these drugs can be difficult because of their transport to affected tissues, inducing non-therapeutic drug levels. Moreover, long-term of these treatments may lead to the selection of resistant HSV, being an additional concern mainly for the immunocompromised patients, which has emphasized the need for alternative strategies [8,9].

Chloroquine diphosphate (CQ) is an antimalarial drug that has been used as the first-line treatment against Plasmodium vivax, Plasmodium ovale, Plasmodium malariae, and Plasmodium falciparum infections. In addition to the antimalarial activity, CQ has been used to treat chronic diseases such as rheumatoid arthritis and systemic lupus erythematosus [10-12]. Recently, this drug has also attracted attention due to its anticancer [13-17] and antiviral activity [18-24]. In this context, CQ is a hydrophilic drug with low toxicity that has shown some limitations to reach an effective intracellular concentration. One of the main disadvantages of the conventional malaria treatment is the non-specific targeting to intracellular parasites, which leads to high dose administration, resulting in toxicity [25].

As expected for antimalarial drugs, the efficacy of antiviral drugs such as CQ depends on their cellular uptake. In attempt to solve this limitation of CQ against HSV-1, the nanodrug delivery systems (NDDS) are known to change drug biodistribution, decrease toxicity, modify drug release rate, and mainly, drug targeting to affected tissues/cell [26]. Among the NDDS, polymeric nanoparticles (NP) is a promising approach to improve drug uptake for a specific cell line. Their advantages include higher stability in biological fluids and easy storage conditions $[27,28]$. Polyesters, such as poly(lactic acid) (PLA) are biocompatible and biodegradable polymers, which are completely eliminated from the body by natural metabolic pathways. Furthermore, PLA is a polymer approved by the Food and Drug Administration (FDA) that has been widely used as a biomaterial for the preparation of nanoparticles for drug delivery [29].

Several methods have been applied to prepare NP. They can be divided into two categories: Those based on the dispersion of preformed polymers and those based on the polymerization of monomers [27]. Considering the dispersion of preformed polymers, the solvent evaporation method or the spontaneous emulsification/solvent diffusion method is a well-consolidated one [30]. Nanoprecipitation (solvent displacement method) is a one-step procedure controlled by the interfacial deposition of the polymer after its displacement from organic to aqueous phase. Due to the fast spontaneous diffusion, nanoparticle formation occurs instantaneously. Emulsification-solvent evaporation method is a two-step procedure in which the organic solution is emulsified in the aqueous phase using a high-speed homogenization or ultrasonication. The formation of NP occurs due to the polymer precipitation after the solvent evaporation [27].

The entrapment of hydrophilic drugs inside hydrophobic polymeric nanoparticles is not an easy task, especially when using the nanoprecipitation method [31,32]. Indeed, hydrophilic drugs have weak interactions with polyesters, such as PLA. Thus, the drug transport from the organic phase to the outer aqueous phase induces low entrapment efficiency. This phenomenon justifies drawbacks of less-well protected drug from degradation and a faster drug release [33]. Some strategies have been used to improve the encapsulation efficiency of hydrophilic molecules in polyester nanoparticles. Controlling $\mathrm{pH}$ of aqueous phase, changes in the solvent phase, use of high drug concentration, and salt addition in the aqueous phase are some examples [30]. 
In the context of anti- HSV-1 activity of CQ [34-37], a specific study reported by Singh et al. (1996) demonstrated the possible mechanism of action of CQ as a promising antiviral drug [38]. This drug has a character of weak base that contributes to increase the intracellular $\mathrm{pH}$, affecting the virus life cycle. In addition. CQ impairs the gD protein transport from trans-Golgi network to cell membrane, which induces the formation of defective viral particles [38]. Thus, this study was performed to improve the encapsulation efficiency of hydrophilic CQ into biocompatible PLA nanoparticles, and to evaluate how the modulation of the drug release affects its anti-HSV activity. The experimental design included different preparation methods, variation in the polymer/drug ratio, and specific parameters such as $\mathrm{pH}$ of aqueous phase. The anti-HSV performance was assessed using Vero E6 cells.

\section{Materials and Methods}

\subsection{Materials}

Chloroquine Diphosphate (CQ), Poloxamer 407 (Pluronic ${ }^{\circledR}$ F-127), and Poloxamer 188 (Pluronic ${ }^{\circledR}$ F-68) were purchased from Sigma-Aldrich (Saint Louis, MO, USA). D,L-poly(lactic acid) (PLA) (inherent viscosity $0.67 \mathrm{dL} \mathrm{g}^{-1}$ at $25^{\circ} \mathrm{C}$ ) was purchased from LACTEL Absorbable Polymers ${ }^{\circledR}$ (Birmingham, AL, USA). Dichloromethane (DCM) (dielectric constant $(\varepsilon)$ of 9.1), ethanol (EtOH) ( $\varepsilon$ of 24.6), acetone (ACE) ( $\varepsilon$ of 20.6) and N-Methyl-2-pyrrolidone (NMP) were purchased from Labsynth ${ }^{\circledR}$ (São Paulo, Brazil). The purified water $\left(1.3 \mu \mathrm{S} \mathrm{cm}^{-1}\right)$ was prepared from reverse osmosis purification equipment, model OS50 LX, Gehaka (Sao Paulo, Brazil). All other reagents have analytical grade.

\subsection{Nanoprecipitation}

CQ-loaded PLA nanoparticles were prepared using the adjusted nanoprecipitation method [39]. Briefly, the CQ was dissolved in $1.8 \mathrm{~mL}$ of a mixture of NMP:water $(1: 5 \mathrm{v} / \mathrm{v})$ and added to $4.2 \mathrm{~mL}$ of a mixture of ACE:EtOH $(1: 1 v / v)$ containing the dissolved PLA. This solution $(6 \mathrm{~mL})$ was injected at

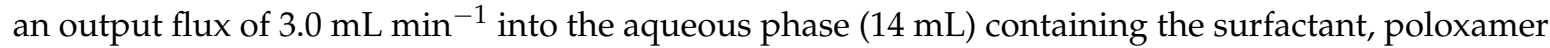
$188(1 \% w / v)$, under magnetic stirring at $720 \mathrm{rpm}$ at $25^{\circ} \mathrm{C}$. Both aqueous and organic phase were previously filtered using a $0.45 \mu \mathrm{m}$ membrane (Sartorius ${ }^{\circledR}$ ). The organic solvent evaporation occurred under magnetic stirring at $720 \mathrm{rpm}$, at $25^{\circ} \mathrm{C}$, overnight. Samples were stored in hermetically sealed glass flasks' at $8^{\circ} \mathrm{C}$ and have the size and zeta potential measured after $24 \mathrm{~h}$. The Blank nanoparticles were prepared carrying out the same procedure without the addition of CQ. All experiments were performed in triplicate, and the data were expressed as mean \pm standard deviation (SD).

\subsubsection{Effect of Drug/Polymer Ratio}

Solutions containing PLA at different concentrations $(0.25 \%, 0.50 \%$, and $0.75 \% w / v)$ were injected in the aqueous phase containing poloxamer 188 at $1 \% w / v$, under magnetic stirring at $720 \mathrm{rpm}$. The drug concentration was fixed in this experiment, resulting in drug/polymer ratios (CQ:PLA) of $1: 5,1: 10$ and $1: 15 w / w$.

\subsection{2. $\mathrm{pH}$ Changes in the Aqueous Phase}

Two different alkalinizing agents were tested to modify the $\mathrm{pH}$ of the outer phase. CQ and PLA concentration were fixed at $0.05 \%$ and $0.5 \% w / v$, respectively in the organic phase $(1: 10 w / v)$, while poloxamer 188 concentration remained fixed at $1.0 \% w / v$ in the aqueous phase. The first aqueous phase has the $\mathrm{pH}$ adjusted to 11.0 , using $0.1 \mathrm{M}$ sodium hydroxide $(\mathrm{NaOH})$. The second tested aqueous phase was produced by adding $0.5 \mathrm{M}$ sodium bicarbonate $\left(\mathrm{NaHCO}_{3}\right)$ with $\mathrm{pH}$ adjusted to 8.4.

\subsection{Emulsification with Solvent Evaporation}

Nanoparticles were also prepared using the adjusted emulsification-solvent evaporation method [40]. Briefly, a small-scale liquid-liquid partition procedure was performed mixing $0.4 \mathrm{~mL}$ of $0.5 \mathrm{M} \mathrm{NaHCO}_{3}$ aqueous solution $(\mathrm{pH}=8.4)(0.4 \mathrm{~mL})$ containing CQ at $1.25 \%$ w/v with $10 \mathrm{~mL}$ of 
organic phase (DCM) containing the PLA $(0.25 \% w / w)$, to obtain CQ:PLA ratio of 1:5 $w / w$. The flask was stirred by vortex for 3 cycles of 10 seconds each, with intervals of 1 min between each cycle. After the partitioning step, the supernatant $\left(\mathrm{NaHCO}_{3}\right.$ solution) was removed and $4 \mathrm{~mL}$ of the organic phase containing CQ and PLA was taken and injected at $1.0 \mathrm{~mL} \mathrm{~min}^{-1}$ into the aqueous phase $(16 \mathrm{~mL})$ containing the surfactant, poloxamer $407(0.75 \% \mathrm{w} / \mathrm{v})$, under magnetic stirring at $720 \mathrm{rpm}$, at $25^{\circ} \mathrm{C}$. The organic and aqueous phases were previously filtered using $0.45 \mu \mathrm{m}$ membranes. Emulsification was produced by using Ultra-turrax equipment stirring (IKA Labortechnik, Germany) for 18 min and evaporation of the solvent at $25^{\circ} \mathrm{C}$, under magnetic stirring at $750 \mathrm{rpm}$, overnight. Samples were stored in hermetically sealed glass flasks at $8^{\circ} \mathrm{C}$ and have the size and zeta potential measured after $24 \mathrm{~h}$. All experiments were performed in triplicate, and the data are expressed as mean \pm standard deviation (SD). The amount of drug at organic phase was analytically determined by UV spectrophotometry at $330 \mathrm{~nm}$. The blank nanoparticles were prepared using the same procedure without the addition of CQ in the buffered solution. All experiments were performed in triplicate, and the data were expressed as mean \pm standard deviation (SD).

\subsection{Particle Size and Zeta Potential Measurements}

Mean particle size and polydispersity index (PdI) were assessed by using Dynamic Light Scattered (DLS) in a particle size analyzer (Brookhaven Instruments, Holtsville, NY, US), at 659 nm wavelength, $90^{\circ}$ detection angle, and at $25^{\circ} \mathrm{C}$. Zeta potential ( $\zeta$ potential) measurements were performed in the same equipment applying a field strength of about $5.9 \mathrm{~V} \cdot \mathrm{cm}^{-1}$ by using the electrophoretic mobility. The measurements were performed for at least ten determinations for each sample diluted at 1:50 $(v / v)$ with purified water. All experiments were performed in triplicate and data were expressed as mean \pm standard deviation (SD).

\subsection{Drug-Loading Efficiency}

Samples were centrifuged at $16,000 \times g$ for $60 \mathrm{~min}$. at $4{ }^{\circ} \mathrm{C}$ using the ultra-centrifugal filter (Sartorius ${ }^{\circledR}$, Vivaspin 2, Ultra-15MWCO $10 \mathrm{kDa}$ ). Drug concentration at the supernatant was assessed using UV-Vis Spectrophometry method at $330 \mathrm{~nm}$ (Thermo Fisher Scientific, 60S Evolution, Madison, WI, US). All analyses were performed in triplicate, and the data were expressed as mean \pm standard deviation (SD). The encapsulation efficiency (EE) was calculated by using the Equation (1), where [Drug $]_{\text {total }}$ is the total drug amount added and [Drug $]_{\text {free }}$ is the non-entrapped drug in supernatant after centrifugation.

$$
\mathrm{EE}(\%)=\frac{[\text { Drug }]_{\text {total }}-[\text { Drug }]_{\text {free }}}{[\text { Drug }]_{\text {total }}} \times 100
$$

\subsection{Atomic Force Microscopy (AFM)}

Shape and surface of the drug-free and CQ-NP were observed by using 2D and 3D AFM images. The dispersions were dropped in a cover slip, dried under desiccator for $24 \mathrm{~h}$, and then, analyzed in an AFM, SPM-9700, Shimadzu (Tokyo, Japan), at room temperature with a cantilever non-contact, $1 \mathrm{~Hz}$ scanning.

\subsection{In Vitro Drug Release}

The drug release profile of CQ-NP was assessed through the in vitro assay using static Franz vertical diffusion cells (Crown Scientific, Sommerville, MA, US), thermostatized at $37 \pm 0.5{ }^{\circ} \mathrm{C}$. In the hermetically sealed donor compartment, $1.0 \mathrm{~mL}$ of formulations were applied and separated from receptor compartment using dialysis membrane with cut-off 12-14 kDa (Sigma-Aldrich), previously hydrated in phosphate buffer $(\mathrm{pH}=7.4)$ for $24 \mathrm{~h}$. The receptor compartment filled with $11.0 \mathrm{~mL}$ of buffer phosphate solution, adjusted to $\mathrm{pH} 7.4$, remained under magnetic stirring at $360 \mathrm{rpm}$ for all experiments. At specific intervals, aliquots of $1.0 \mathrm{~mL}$ were taken for UV spectrophotometry analysis at $330 \mathrm{~nm}$, previously validated. The same volume of freshly buffer solution replaced the medium to 
maintain the sink conditions. The experiment was also performed for free CQ in aqueous solution, as control. All analyses were performed in triplicate and data were expressed as mean \pm standard deviation (SD).

\subsection{Cells and Viruses}

Vero E6 cells (continuous cell lineage originated from the kidney of African green monkeys), were kindly donated by the Department of Internal Medicine, School of Medicine of Ribeirão Preto-University of Sao Paulo-USP, Brazil. The cells were maintained at $37{ }^{\circ} \mathrm{C}$ and $5 \% \mathrm{CO}_{2}$ and cultured in Leibovitz-15 culture medium (L-15) with L-glutamine (Invitrogen, New York, NY, US) supplemented with $2 \%$ or $10 \%$ of fetal bovine serum (FBS), $1 \%$ of antibiotic-antimycotic solution $100 \mathrm{X}$ $\left(\right.$ Gibco $\left.^{\circledR}\right)$, and $10 \%$ of triptose phosphate $[19,20]$.

The virus HSV-1 (strain KOS) was kindly provided by Dra. Cláudia Maria Oliveira Simões and Msc. Laurita Boff, from the College of Pharmacy, Federal University of Santa Catarina, Brazil. The virus was propagated and titrated by plaque-forming units assay (PFU) on Vero E6 cells [41]. Viral stocks were stored at $-80{ }^{\circ} \mathrm{C}$ until use.

\subsection{Cell Viability Studies}

The viability of Vero cells following exposure for 24-48 $\mathrm{h}$ at different concentrations of CQ, CQ-NP and blank nanoparticles (B-NP) was assessed using the 3-(4,5-dimethylthiazol-2-yl)-2,5-diphenyltetrazolium bromide (MTT) method. Briefly, Vero cells $\left(2 \times 10^{4}\right.$ cells/well) were cultured in 96-well plates in L-15 medium with $10 \%$ of FBS and maintained at $37{ }^{\circ} \mathrm{C}$ and $5 \% \mathrm{CO}_{2}$. After $24 \mathrm{~h}$, the cells were exposed to decreasing concentrations (30, $20,10,5$, and $2.5 \mu \mathrm{g} \mathrm{mL}^{-1}$ ) of CQ and a two-fold serial dilution of nanoparticles (range 500-7.81 $\mu \mathrm{g}$ $\mathrm{mL}^{-1}$ ) solution suspended in medium supplemented with $2 \%$ of FBS. Before the cytotoxicity assay, CQ dissolved in L-15 at 2\% were filtered through a $0.22 \mu \mathrm{m}$ sterile filter (Sartorius ${ }^{\circledR}$ ), and CQ-NP and B-NP were filtered through a $0.45 \mu \mathrm{m}$ sterile filter (Sartorius ${ }^{\circledR}$ ). After 24 and $48 \mathrm{~h}$ of incubation, medium was collected and $50 \mu \mathrm{L}$ of MTT (Sigma, Germany, ref.: M2128-1G) solution $\left(1 \mathrm{mg} \mathrm{mL}^{-1}\right) \mathrm{was}$ added per well. Plates were, then, incubated for $4 \mathrm{~h}$ at $37^{\circ} \mathrm{C}$ and $5 \% \mathrm{CO}_{2}$. Posteriorly, $100 \mu \mathrm{L}$ of DMSO was added in each well and the absorbance was measured at $540 \mathrm{~nm}$ in a microplate reader (Biotek ${ }^{\circledR}$, Epoch model). All measurements were carried out in triplicate (three plates) with three replicates for each dilution. The cell viability was defined in comparison to untreated controls. The relative cell viability $(\%)$ in the sample treated wells with respect to the control wells was estimated by the Equation (2):

$$
\% \text { Cell Viability }=\left[\frac{(\mathrm{A}) \text { tested }}{(\mathrm{B}) \text { control }}\right] \times 100
$$

where (A) tested and (B) control are the absorbance of treated sample and control sample, respectively. All experiments were set up in triplicates.

For the determination of the cytotoxic concentration $\left(\mathrm{CC}_{50}\right)$ values, nonlinear regression of concentration-response curves was used. The $\mathrm{CC}_{50}$ was defined as the concentration that reduced cell viability by $50 \%$ when compared to untreated controls.

\subsection{Cell Infection}

For this assay, the titer of the virus preparation was $3.75 \times 10^{7} \mathrm{PFU} / \mathrm{mL}$. For the plaque reduction assay, Vero cell monolayers were infected with $100 \mathrm{PFU} /$ well of the HSV-1 for $1 \mathrm{~h}$ at $37^{\circ} \mathrm{C}$. The inoculum with non-attached viral particles was removed and the cells were washed with PBS. Finally, the infected cells were treated according to the assay. 


\subsection{Antiviral Activity}

The CQ, CQ-NP, and B-NP were tested for antiviral activity against HSV-1 by the plaque reduction assay. This assay was performed according to the standard method described Caldas dos Santos, 2017 [41] and Beram-Pinto, 2009 [42]. Vero cells were seeded in 24-well plates $\left(2 \times 10^{5}\right.$ cells/well) and infected with HSV-1 diluted in medium without supplement (100 PFU/well) for $1 \mathrm{~h}$ at $37^{\circ} \mathrm{C}$, except for the negative controls. After incubation, the viral inoculum was removed and the monolayers were washed with PBS. Subsequently, L-15 medium containing 3\% of carboxymethyl-cellulose (CMC; Saint Louis, MO, USA) (overlay) was added and plates incubated at $37^{\circ} \mathrm{C}$ for $48 \mathrm{~h}$ and overlaid, in duplicate, with L-15 containing $2 \%$ of CMC in the presence or absence of different non-cytotoxic concentrations $\left(30,20,10,5\right.$, and $\left.2.5 \mu \mathrm{g} \mathrm{mL}{ }^{-1}\right)$ of the test compound. The plates were, then, incubated for $48 \mathrm{~h}$ at $37^{\circ} \mathrm{C}$. After this period, the medium in the wells was removed and the cells were stained with naphthol blue-black (Sigma). The number of plaques in each well were then counted. All measurements were carried out in duplicate (two plates) with three replicates for each dilution. The percent of inhibitory of any concentration was determined using the Equation (3).

$$
\% \text { of inhibition }=\left[1-\frac{(\text { number of plaque }) \text { tested }}{\text { Number of viral control plaque }}\right] \times 100
$$

The concentration of treatments that reduced viral replication by $50 \%\left(\mathrm{IC}_{50}\right)$ was calculated by regression analysis of the dose-response curves generated from the data. Viral controls were considered with $0 \%$ of inhibition because they are not receiving any treatment. The ratio between $\mathrm{CC}_{50}$ and $\mathrm{IC}_{50}$ values was calculated to obtain the selectivity index (SI) of each sample. Acyclovir (ACV; Pharma nostra; China) was used as positive control.

\subsection{Statistical}

All experimental values were expressed as mean \pm standard deviation (SD). The pairwise comparisons of the analytical data were performed using the Student's t-test. For the antiviral assay and cell viability, the multiple comparisons were performed using analysis of variance (ANOVA) at $p=0.05$ significance level, followed by Bonferroni's test and Dunnett's test [43,44].

\section{Results}

\subsection{Preparation of Drug-Loaded Nanoparticles by the Nanoprecipitation Method}

Small CQ-NP were successfully prepared using the parameters selected for the nanoprecipitation method. For each experiment B-NP were produced using the same experimental parameters in absence of drug. The NP $<250 \mathrm{~nm}$ with negative zeta potential and narrow particle size distribution (PdI $<0.2$ ) were identified for tested formulations (Table 1). Three different CQ:PLA ratios were tested (Formulations $1-3)$ using the same slightly acid aqueous phase $(\mathrm{pH}=6.4)$. However, EE\% levels less than $11 \%$ were identified for these samples, which decreased according to the CQ: PLA ratio (from $10.6 \%$ to $3.4 \%$ ). In addition, the zeta potential becomes more negative (from $-3.13 \mathrm{mV}$ to $-14.42 \mathrm{mV}$ ). Due to the $\mathrm{pH}$-dependent solubility character of the $\mathrm{CQ}$, two alkaline aqueous phases were tested aiming to improve the EE\% (Formulations 4 and 5) (Table 1). Using $0.1 \mathrm{M} \mathrm{NaOH}$ as alkalizing agent (Formulation 4), it was possible to achieve an $\mathrm{EE} \%$ of about $11.4 \%$. On the other hand, the Formulation 5 , produced using $0.5 \mathrm{M} \mathrm{NaHCO}_{3}$, induced an $\mathrm{EE} \%$ of about $25 \%$. 
Table 1. Physicochemical properties of blank nanoparticles (B-NP) and respective CQ-NP produced by the nanoprecipitation method.

\begin{tabular}{ccccccc}
\hline Formulation & $\mathbf{C Q}^{\mathbf{1}} \mathbf{\text { :PLA }}{ }^{\mathbf{2}}$ Ratio & $\mathbf{A P}^{\mathbf{3}} \mathbf{p H}$ & Size $(\mathbf{n m})$ & $\mathbf{P d I}^{\mathbf{4}}$ & $\mathbf{Z P}^{\mathbf{5}} \mathbf{( m V )}$ & EE $^{\mathbf{6}}\left(\mathbf{\%}^{\mathbf{m}}\right)$ \\
\hline B-NP & 0 & 6.4 & $106.2 \pm 2.5$ & $0.157 \pm 0.03$ & $-7.95 \pm 3.2$ & \\
1 & $1: 5$ & 6.4 & $173.5 \pm 8.5$ & $0.113 \pm 0.04$ & $-3.13 \pm 3.2$ & $10.6 \pm 1.3$ \\
2 & $1: 10$ & 6.4 & $189.1 \pm 6.5$ & $0.080 \pm 0.03$ & $-6.85 \pm 5.3$ & $8.4 \pm 2.6$ \\
3 & $1: 15$ & 6.4 & $226.4 \pm 9.2$ & $0.073 \pm 0.03$ & $-14.42 \pm 2.1$ & $3.4 \pm 1.4$ \\
B-NP & 0 & 11.0 & $114.5 \pm 6.0$ & $0.089 \pm 0.02$ & $-1.91 \pm 0.8$ & \\
4 & $1: 10$ & 11.0 & $200.6 \pm 11.4$ & $0.069 \pm 0.01$ & $-18.15 \pm 3.3$ & $11.4 \pm 2.0$ \\
B-NP & 0 & 8.4 & $118.6 \pm 6.0$ & $0.046 \pm 0.01$ & $-11.63 \pm 3.0$ & \\
5 & $1: 10$ & 8.4 & $231.4 \pm 11.5$ & $0.096 \pm 0.02$ & $-5.68 \pm 4.1$ & $25.0 \pm 1.6$ \\
\hline
\end{tabular}

Note: Data are expressed as mean \pm standard deviation $(n=3) .{ }^{1} \mathrm{CQ}$, chloroquine diphosphate; ${ }^{2}$ PLA, poly(lactic acid); ${ }^{3} \mathrm{AP}$, aqueous phase; ${ }^{4} \mathrm{PdI}$, polydispersity index; ${ }^{5} \mathrm{ZP}$, zeta potential; ${ }^{6} \mathrm{EE} \%$, encapsulation efficiency.

\subsection{Preparation of Drug-Loaded Nanoparticles by the Emulsification-Solvent Evaporation Method}

In this approach, an adjusted emulsification-solvent evaporation method was used, applying a small-scale liquid-liquid partition to provide the maximum concentration of chloroquine free base (CQ-fb) in the organic phase. All experiments have the CQ-fb amount in organic phase analytically controlled using UV spectrophotometry. An average level of $97.51 \%$ of CQ-fb dissolved in the DCM was achieved. NP $<300 \mathrm{~nm}$ with negative zeta potential and PdI of about 0.3 were produced using the selected parameters (Table 2). The strategy to induce CQ-fb in an immiscible organic phase structured as droplets dispersed in an alkaline $0.5 \mathrm{M} \mathrm{NaHCO}_{3}$ aqueous solution $(\mathrm{pH}=8.4)$ provided an excellent $\mathrm{EE} \%$ of $64.1 \%$. This formulation (formulation 6 ) was then selected for further studies.

Table 2. Physicochemical properties of B-NP and CQ-NP (formulation 6) produced by the emulsification-solvent evaporation method and their fitting parameters of different kinetic models applied for the in vitro drug release experiments.

\begin{tabular}{|c|c|c|c|c|c|c|c|c|}
\hline \multirow{2}{*}{ Formulation } & \multicolumn{4}{|c|}{ Physicochemical Properties } & \multicolumn{4}{|c|}{ Kinetic Models $[k(\mathrm{R})]$} \\
\hline & Size (nm) & PdI $^{1}$ & $\mathrm{ZP}^{2}(\mathrm{mV})$ & $\mathrm{EE}^{3}(\%)$ & First Order & Bhaskar & Freundlich & Parabolic \\
\hline B-NP & $283.9 \pm 53.2$ & $0.27 \pm 0.05$ & $-25.4 \pm 11.6$ & - & - & - & - & - \\
\hline
\end{tabular}

Note: Data are expressed as mean \pm standard deviation $(n=3) .{ }^{1} \mathrm{PdI}$, polydispersity index; ${ }^{2} \mathrm{ZP}$, zeta potential;

${ }^{3} \mathrm{EE}$, encapsulation efficiency; values of drug release rate constant $(k)$; correlation coefficient $(R)$.

\subsection{Morphology}

The shape and surface of B-NP and CQ-NP (formulation 6) produced by the emulsification-solvent evaporation method were assessed using 2D and 3D Atomic Force Microscopy (AFM) images (Figure 1). Both nanoparticle formulations have shown spherical shape and slight smooth surface. 


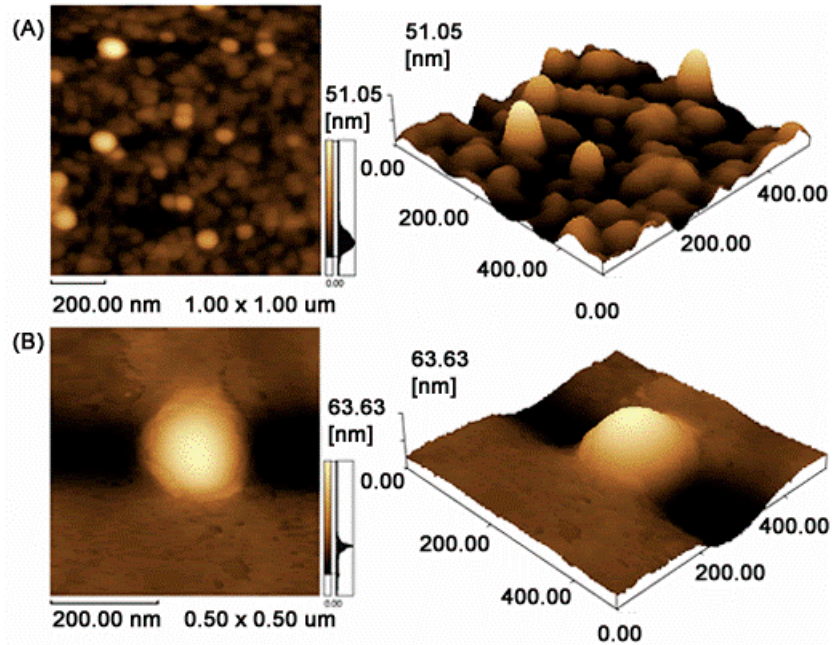

Figure 1. AFM images of (A) blank nanoparticles and (B) drug-loaded nanoparticles in 2D and 3D, respectively.

\subsection{In Vitro Drug Release}

The drug release experiment was performed for the formulation 6, produced by emulsification with solvent evaporation method. Its drug release profile is shown in Figure 2. The CQ-loaded NP exhibited the desired slow drug release profile, compared to the free CQ drug aqueous solution.

Data were subjected to four different diffusion kinetic linear models, which include the first-order model (Figure 2B), the Bhaskar model (Figure 2C), the Freundlich model (Figure 2D), and the parabolic model (Figure 2E). The drug release rate constant $(k)$ and correlation coefficients $(R)$ from distinct kinetic models are shown in the Table 2. The parabolic diffusion model fitted the CQ release from PLA nanoparticles better than the others mathematical models, giving a linear correlation coefficient of 0.95 .
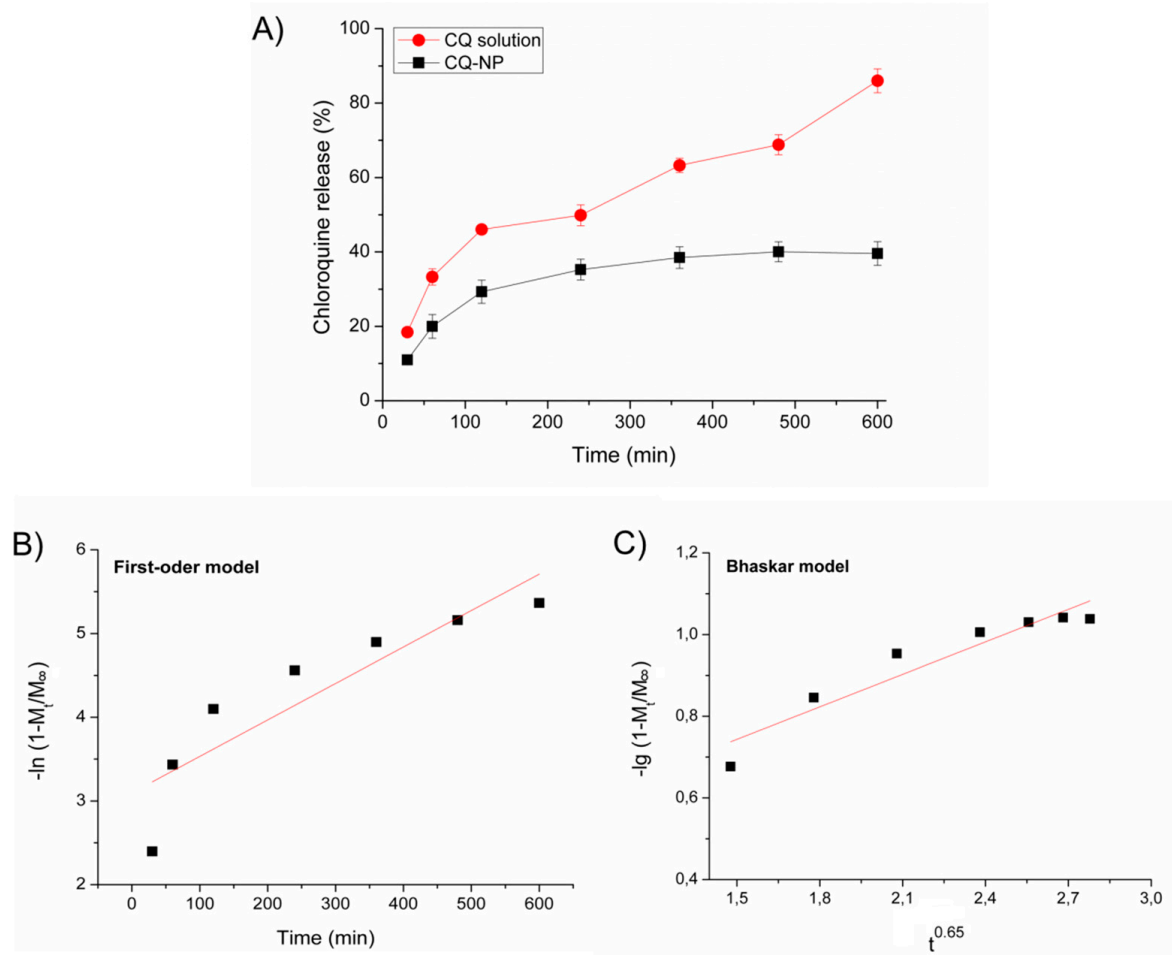

Figure 2. Cont. 

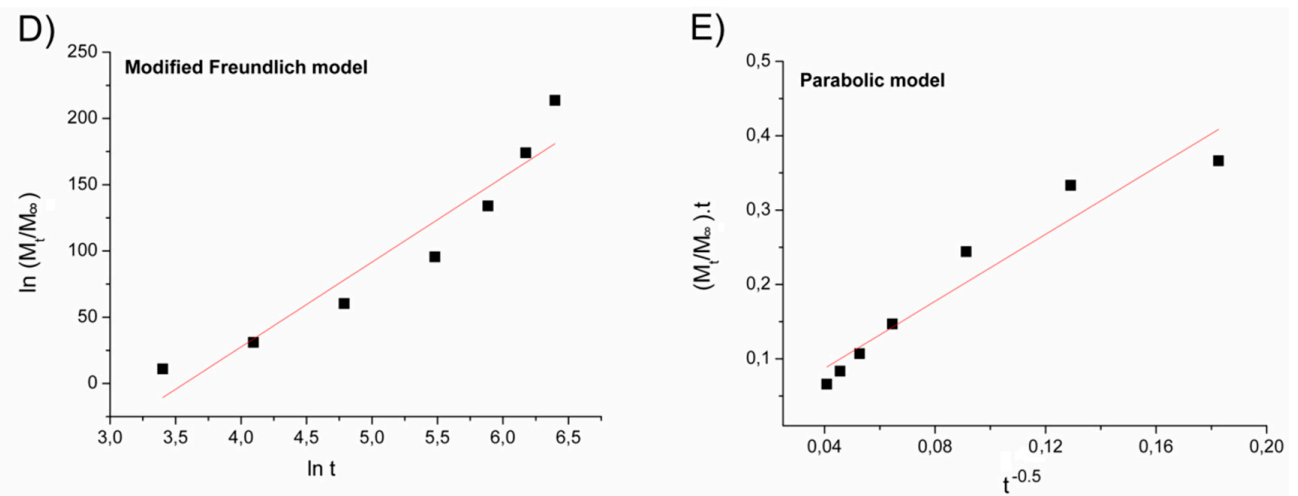

Figure 2. Experimental in vitro release profile of (A) chloroquine (CQ) solution $(\bullet)$ and chloroquineloaded nanoparticles (CQ-NP) ( $\square$ ) from different samples and respective mathematical modeling adjustment of nanoparticles of data using: (B) first-order model; (C) Bhaskar model; (D) modified Freundlich model; and (E) Parabolic model. Notes: The data are expressed as mean \pm standard deviation (SD) $(n=2)$.

\subsection{Cell Viability Studies}

Before the experiments of the antiviral activity, the cytotoxicity of CQ, CQ-NP (formulation 6) and B-NP in Vero E6 cells using the MTT assay was evaluated (Figure 3). The B-NP have shown no cytotoxic effect at the concentration range from seven to $500 \mu \mathrm{g} \mathrm{mL} \mathrm{L}^{-1}$, for $24 \mathrm{~h}$ and $48 \mathrm{~h}$ (Figure $3 \mathrm{~A}, \mathrm{~B}$ ). On the other hand, the drug (CQ) exhibited a cytotoxic concentration-dependent profile, which was time-dependent (Figure 3A,B). In addition, the serial dilution $\left(500-7.81 \mu \mathrm{g} \mathrm{mL}^{-1}\right.$ ) suggested no significant cytotoxicity to treated cells with these formulations at concentrations $\leq 62.5 \mu \mathrm{g} \mathrm{mL}^{-1}$, for $48 \mathrm{~h}$.

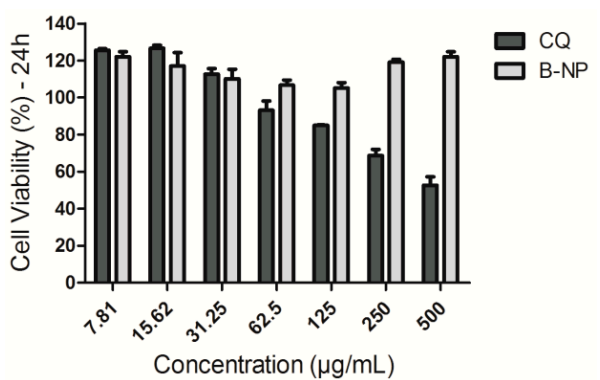

(A)

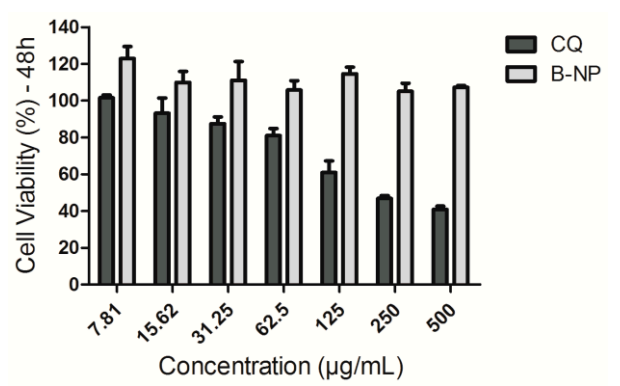

(B)

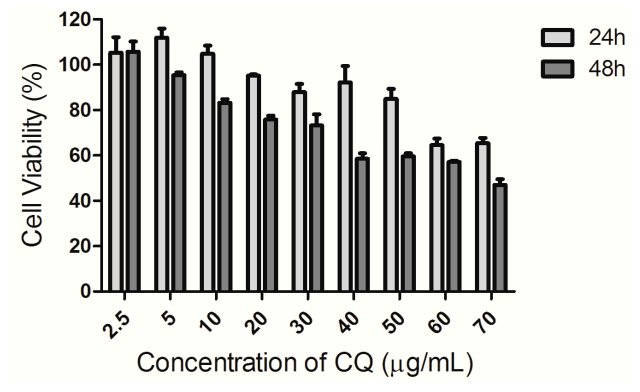

(C)

Figure 3. Cell viability in Vero E6 cells. Assay performed after the incubation of CQ and B-NP samples after (A) $24 \mathrm{~h}$ and (B) $48 \mathrm{~h}$ of incubation, respectively; and (C) assay performed after $24 \mathrm{~h}$ and $48 \mathrm{~h}$ of incubation for CQ-NP sample. Concentrations lower than $62.5 \mu \mathrm{g} \mathrm{mL} \mathrm{L}^{-1}$ for $\mathrm{CQ}$, and $30 \mu \mathrm{g} \mathrm{mL}-1$ for CQ-NP exhibited low cell cytotoxicity when compared to untreated controls. On the other hand, all tested concentrations for B-NP did not induce significant cytotoxicity. 
The experiment with CQ-NP considered a serial dilution $\left(70-2.5 \mu \mathrm{g} \mathrm{mL}^{-1}\right)$ to evaluate the effect of NP on the drug toxicity at the same conditions of the anterior experiments (Figure 3C). The concentration of $70 \mu \mathrm{g} \mathrm{mL}{ }^{-1}$ was used as starting point for serial dilution, once cell viability above $80 \%$ was achieved after the treatment with a CQ at $62.5 \mu \mathrm{g} \mathrm{mL}{ }^{-1}$. As observed for CQ (Figure $3 \mathrm{~A}, \mathrm{~B}$ ), the CQ-NP samples also exhibited a concentration and time-pendent cytotoxicity profile (Figure 3C). The $\mathrm{NP}$ increased the cytotoxic effect of the drug at the similar concentration range, suggesting greater drug uptake by the cells. The average $\mathrm{CC}_{50}$ identified for free-CQ drug was more threefold $\left(222.6 \mu \mathrm{g} \mathrm{mL}^{-1}\right)$ than that for CQ-NP $\left(67.9 \mu \mathrm{g} \mathrm{mL}^{-1}\right)$ (Table 3 ). In addition, the cell viability $\geq 80 \%$ was observed just for concentration levels lower than $30 \mu \mathrm{g} \mathrm{mL}^{-1}$. This achievement was fundamental to choose the concentration range ( 30 to $2.5 \mu \mathrm{g} \mathrm{mL}^{-1}$ ) to be used in further in vitro infectious assays for B-NP, CQ, and CQ-NP.

Table 3. Cytotoxicity and parameters of anti-HSV-1 activity evaluated for chloroquine (CQ), blank PLA nanoparticles (B-NP) and chloroquine-loaded PLA nanoparticles (CQ-NP) in Vero E6 cells.

\begin{tabular}{|c|c|c|c|}
\hline Samples (Treatment $48 \mathrm{~h}$ ) & $\begin{array}{c}\mathrm{CC}_{50}{ }^{1} \\
\left(\mu \mathrm{g} \mathrm{mL}^{-1}\right)\end{array}$ & $\begin{array}{c}\mathrm{IC}_{50}{ }^{2} \\
\left(\mu \mathrm{g} \mathrm{mL}^{-1}\right)\end{array}$ & $\mathrm{SI}^{3}$ \\
\hline B-NP & $>500$ & ${ }^{4}$ N.A & - \\
\hline CQ & $222.6 \pm 5.4$ & $6.7 \pm 0.6$ & 33.0 \\
\hline CQ-NP & $67.9 \pm 2.1$ & $4.3 \pm 1.4$ & 15.6 \\
\hline
\end{tabular}

Note: Data are expressed as mean \pm standard deviation (SD) from three independent experiments with each treatment performed in triplicate. ${ }^{1} \mathrm{CC}_{50}=$ concentration that was cytotoxic for $50 \%$ of the Vero cells; ${ }^{2} \mathrm{IC}_{50}=$ concentration that inhibited viral replication by $50 \%$ in the post-treatment conditions; ${ }^{3} \mathrm{SI}=$ selectivity index, calculated from the ratio of $\mathrm{CC}_{50}$ and $\mathrm{IC}_{50} ;{ }^{4} \mathrm{~N}$.A: No activity.

\subsection{Antiviral Activity}

The HSV-1 activity of B-NP, CQ, and CQ-NP (formulation 6) in the infected Vero E6 cells were assessed using the standard plaque reduction assay $[45,46]$. The $\mathrm{CC}_{50}$ and $\mathrm{IC}_{50}$ values (Table 3 ) were determined by nonlinear regression of the concentration-response curves. As expected, B-NP did not show anti-herpetic activity against the HSV-1 at the tested concentration range $\left(2.5-30 \mu \mathrm{g} \mathrm{mL}^{-1}\right)$. The average $\mathrm{IC}_{50}\left(6.7 \mu \mathrm{g} \mathrm{mL}^{-1}\right)$ and SI values (33.0) assayed for CQ were considerable larger than that for CQ-NP $\left(4.3 \mu \mathrm{g} \mathrm{mL}{ }^{-1}, 15\right)$. All the three distinct parameters evaluated have demonstrated the superior anti-HSV-1 efficacy of CQ-NP.

Further experiments aiming to evaluate the anti-herpetic activity of the formulations were performed after virus adsorption. Acyclovir $(20 \mu \mathrm{g})$, the first-line drug for the treatment of HSV infections, was used as positive control, whereas untreated infected cells were used as negative control. The treatment with different concentrations of samples for $48 \mathrm{~h}$ post-infection (p.i) showed a dose-dependent viral inhibition by both CQ and CQ-NP $(p<0.001)$ (Figure 4A). The results suggested that CQ showed the ability to inhibit $100 \%$ of viral replication at $30 \mu \mathrm{g} \mathrm{m}^{-1}$, whereas, for CQ-NP, this effect was observed at $10 \mu \mathrm{g} \mathrm{mL}^{-1}$ (Figure $4 \mathrm{~A}$ ). At the concentration range from 5 to $20 \mu \mathrm{g} \mathrm{mL}^{-1}$, the CQ-NP had an inhibitory activity considerable higher than CQ with $p<0.001$. ( $\left.{ }^{* * *}\right)$. Moreover, a smaller difference $p<0.05\left(^{*}\right)$ was observed at the concentration of $2.5 \mu \mathrm{g} \mathrm{mL} \mathrm{m}^{-1}$. The treatment of Vero E6 infected cells with all tested concentrations of B-NP did not show significant activity against the virus (Figure $4 B$ ), once the inhibition of viral replication was significantly different from the positive control with $p<0.001{ }^{(* * *)}$. 


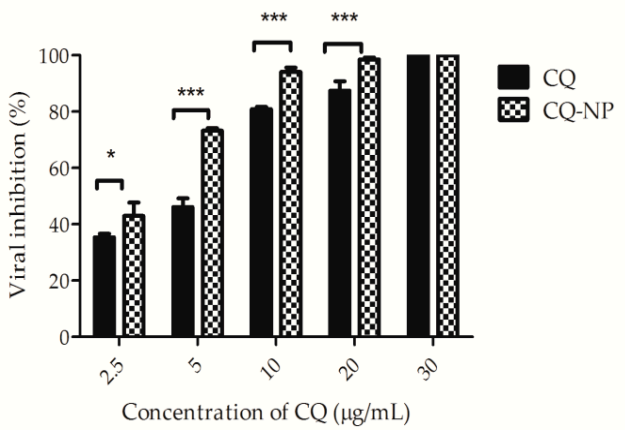

(A)

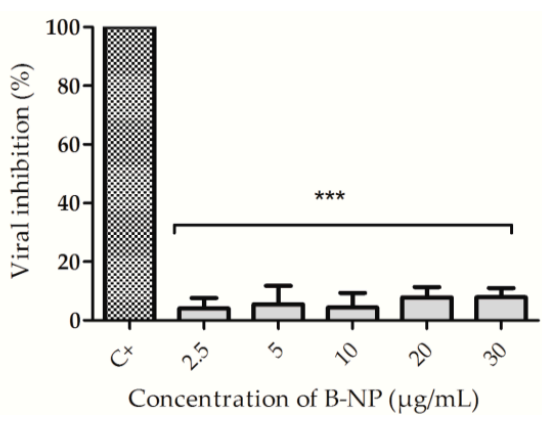

(B)

Figure 4. Antiviral activity of chloroquine (CQ), chloroquine loaded PLA nanoparticles (CQ-NP), and blank nanoparticles (B-NP). (A) Viral inhibition percentage after treatment for 48h with CQ and CQ-NP; and (B) viral inhibition percentage after treatment for $48 \mathrm{~h}$ with B-NP. The positive control $\left(\mathrm{C}^{+}\right)$of all experiments was acyclovir $\left(20 \mu \mathrm{g} \mathrm{mL}^{-1}\right)$. Notes: The data were expressed as mean \pm standard deviation (SD) $(n=3),\left({ }^{*}\right): p<0.05$ and $\left({ }^{* * *}\right): p<0.001$. The experiments were analyzed by the Two-way ANOVA following by the Bonferroni's test (A) and the One-way ANOVA followed by the Dunnett's test (B).

\section{Discussion}

In this study, the feasibility of biodegradable PLA nanoparticles as a promising approach to improve antiviral activity of Chloroquine diphosphate (CQ) has been investigated. Small biodegradable nanoparticles have the ability to overcome biological barriers, such as the efflux cotransport proteins at cell membrane and until brain-blood barrier [26,29]. In this context, Vero E6 cells were infected with a common human pathogen, the herpes simplex virus type 1 (HSV-1). The antiviral activity of CQ has been reported in the literature [18-24]. However, its anti-HSV-1 activity was not yet been well described. Indeed, due to the similar characteristic with previous described virus infections studies using CQ, a promising effect against HSV-1 infection could be hypothesized using this drug. In addition, its encapsulation in the biodegradable and biocompatible NP could solve its non-specific targeting against intracellular pathogens [25].

The biocompatible and biodegradable poly(lactic acid) (PLA) was chosen for this purpose. However, this polymer is a hydrophobic polyester [29] and produce NP for encapsulating hydrophilic drugs, such as the CQ, consists of an interesting challenge [30,31]. Thus, two different methods of preparation of nanoparticles well applied for this class of polymer were carefully tested. The small size of the system and the drug encapsulation efficiency (EE) were selected as the main performance parameters. Physicochemical properties of the formulations produced by the nanoprecipitation method revealed that the drug/polymer ratio directly affected both particle size and EE\% (Table 1). As expected, the particle size increased according to the polymer concentration in the organic phase. This effect generally improves the $\mathrm{EE} \%$ of hydrophobic drugs [32,33,47,48]. In contrast to this fact, Formulations 1,2 , and 3 showed low EE\%, which decrease with the polymer increment. Chloroquine Diphosphate (CQ) is a low-weight drug with multiple pKas, and solubility behavior dependent on $\mathrm{pH}$. At this $\mathrm{pH}=6.4$, this hydrophilic compound is unable to favorable interaction with hydrophobic polyesters such as PLA. The increment of PLA leads to drug displacement from organic phase to aqueous phase, resulting in low entrapment efficiency [30-33,49].

The experimental results with formulations one-three provided important achievements about the relationship between the solubility behavior of CQ and its interaction with the PLA. Thus, the $\mathrm{pH}$ of the aqueous phase, initially controlled at $\mathrm{pH}=6.4$, was adjusted to an alkaline range to increase the non-ionized fraction of CQ. This strategy can potentially improve the EE\%, mainly considering hydrophilic drugs [33]. The central drug/polymer ratio of 1:10 was chosen for this purpose. Alkalinizing the aqueous phase $(\mathrm{pH}=11.0)$ with $\mathrm{NaOH}$ in the Formulation 4 made possible 
improve the average $\mathrm{EE} \%$ from $8.4 \%$ to $11.4 \%$. Alkalinizing aqueous phase with $\mathrm{NaHCO}_{3}$ for $\mathrm{pH}=8.4$ in Formulation 5 proved to be more efficient, inducing an average EE $\%$ of about $25 \%$. Previous studies have reported that $\mathrm{CQ}$ degradation is accelerated in $0.1 \mathrm{M} \mathrm{NaOH}$ media, by a hydrolysis mechanism [50]. The hypothesis of drug precipitation in the aqueous phase, due to the strongest alkaline $\mathrm{pH}$, should also be considered.

The dispersions prepared at $\mathrm{pH}=6.4$ showed negative zeta potential $(-3.13 \mathrm{mV}$ to $-14.42 \mathrm{mV})$ due to the terminal acid carboxyl groups of PLA (Table 1) [51]. Two main stabilization mechanisms for colloidal suspensions should be considered. The electrostatic repulsion, in which adding ionic stabilizers, and the steric stabilization that can be achieved by non-ionic stabilizers into the medium. The formulations described in the present study are stabilized using poloxamer 188, a non-ionic and copolymer stabilizer agent. The steric stabilization is dominated by solvation effect [52]. Thus, $\mathrm{pH}$ changes or changes in drug/polymer ratio not necessary induces monotonically change in the zeta potential, as occurred in this approach (Table 1). This value slightly increased for Formulation 3 with the largest PLA content. When the PH increased for alkaline range (eight and eleven), the zeta potential remained negative, as expected.

The selected parameters for the emulsification-solvent evaporation method induced larger particles compared to that produced by the nanoprecipitation technique (Table 2). NP have shown negative zeta potential and narrow particle size (PdI $=0.3)$ with mean diameter $<300 \mathrm{~nm}$. The best results using the nanoprecipitation method were reached using the CQ:PLA ratio of 1:5 w/w and $0.5 \mathrm{M} \mathrm{NaHCO}_{3}$ aqueous solution $(\mathrm{pH}=8.4)$. These work conditions were repeated for the emulsification-solvent evaporation method, with an excellent average EE\% level of about $64.1 \%$. This fact corroborated with the successful partition of CQ-fb to the organic phase and the importance of the alkaline aqueous phase to maintain the drug and polymer in the droplets of the emulsion. The $\mathrm{pH}$ of the aqueous phase $\left(0.5 \mathrm{M} \mathrm{NaHCO}_{3}, \mathrm{pH}=8.4\right)$ assured a maximum of non-ionized of chloroquine's amine groups $\left(\mathrm{Pka}_{1}=8.4, \mathrm{Pka}_{2}=10.8\right)$, compared to the previous tested aqueous phase $(\mathrm{pH}=6.4)$. At contact with the organic immiscible solvent (DCM), the phase equilibrium between the ionized and the non-ionized species of CQ in the aqueous phase changes constantly, with the partition of non-ionized specie of the drug to the interface, and finally to the organic solvent. The displacement of non-ionized molecules of drug occurs until its exhaustion and transport of the total amount to the organic phase, as suggested, for example, in the Figure 5. The mass ratio maintained between the two phases could be explained by the principle of mass conservation.

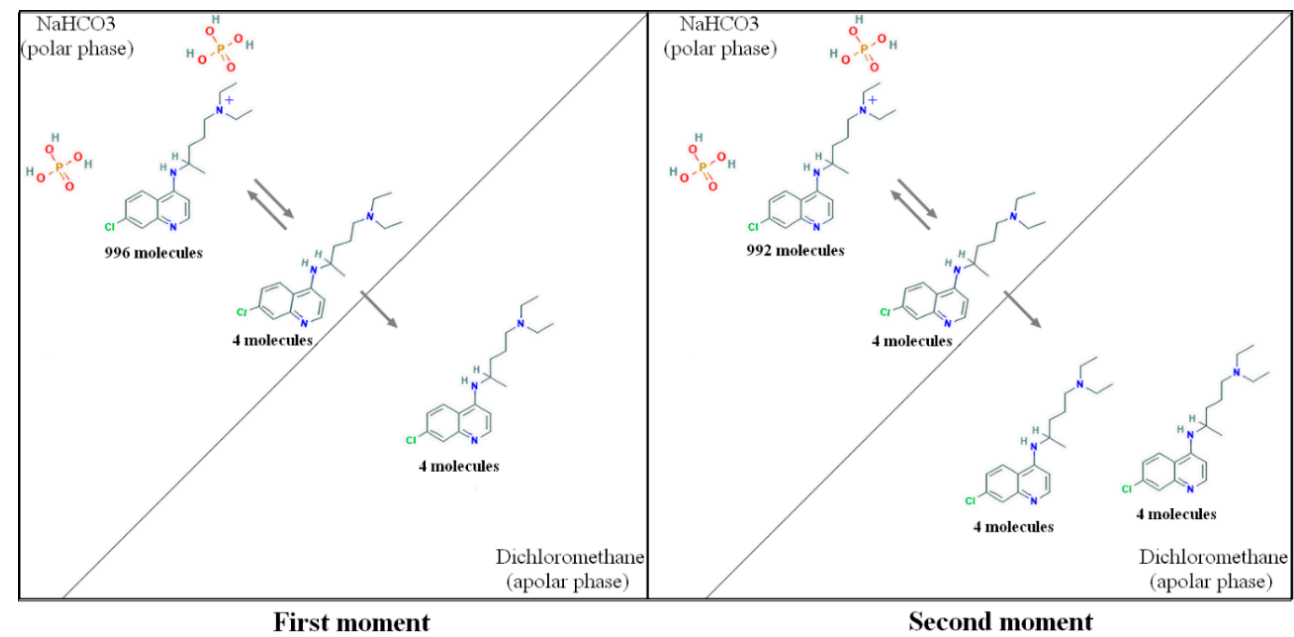

Figure 5. Suggested chloroquine partitioning scheme. At the first moment, a theoretical maximum ratio of ionized chloroquine molecules occurs in the polar phase following by a gradually partitioning to the organic phase at the second moment. This transport follows until the exhaustion with the total partition of the drug to the organic apolar phase. 
The Formulation 6 was selected for further experiments. The AFM images (Figure 1) suggested spherical NP with slightly smooth surface. It was also possible to observe NP in the range of $200 \mathrm{~nm}$, corroborating to the DLS experiments. Hoo et al. (2008) reported some differences among AFM and DLS experiments, mainly due to the differences in sample preparing procedures, which can induce some particle agglomeration [53].

The Formulation 6 was able to generate the desired slow drug release, corroborating with the drug-loading experiments (Figure 2). Considering the emulsification-solvent evaporation method, the $\mathrm{EE} \%$ level superior to $60 \%$ is considered excellent, which induced a slow drug release profile adjusted by the parabolic diffusion mathematical model ( $r \geq 0.95)$ (Table 2). This fact suggested a diffusion-controlled transport of CQ from the polymeric matrix of NP [43]. In addition, it is important to note that, on the best of our knowledge, no data in the literature describes the slow chloroquine release from PLA nanoparticles. Previous studies have shown a release of $52.40 \%$ of hydroxyl chloroquine

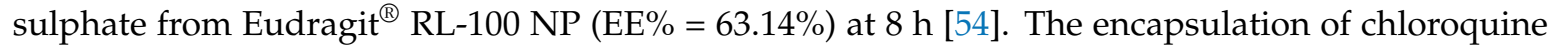
diphosphate was described in chitosan NP prepared by ionic gelation technique $(\mathrm{EE} \%=59.5 \%)$, which induced the release of $40 \%$ of the drug at $24 \mathrm{~h}$ [55]. In the present study, the amount of drug released at $10 \mathrm{~h}$ was about $40 \%$, which is much slower than the previously cited studies. In this approach, the residual amount of non-ionized specie of CQ loaded into PLA nanoparticles seems to be strongly interacting with PLA matrix. The parabolic model fitted the experimental data much better $(r=0.95)$ (Figure 2E), which suggested a drug release controlled by diffusion at the first moment. However, the erosion of polymeric matrix of particles should also be considered for release of residual entrapped drug, which could occur in a second moment [44,48,49,51].

This ability of colloidal nanocarriers to preserve the entrapped drug into the polymeric matrix is a promising characteristic for drug targeting intended for specific affected cell or tissue, mainly considering the internalization of nanoparticles by endocytosis $[43,56,57]$.

The assessed physicochemical and feasible properties of the Formulation 6 suggested an interesting and promising PLA NP system for CQ targeting. Thus, studies for evaluating its cytotoxicity and its anti-HSV-1 activity were performed. The cell viability experiments demonstrate the absence of cytotoxic effect of blank PLA NP (B-NP) in the tested concentration range (7.81-500 $\mu \mathrm{g} \mathrm{mL}^{-1}$ ) for $24 \mathrm{~h}$ (Figure $3 \mathrm{~A}$ ) and $48 \mathrm{~h}$ of incubation (Figure 3B). In addition, it was possible to suggest that PLA NP improved CQ uptake, because CQ-NP have shown cell viability levels lower than that observed for free $C Q$ drug at the same tested concentration range (Figure $3 C$ ). The $\mathrm{CC}_{50}$ identified for $\mathrm{CQ}$ $\left(222.6 \mu \mathrm{g} \mathrm{mL}^{-1}\right)$ and CQ-NP $\left(67.9 \mu \mathrm{g} \mathrm{mL}^{-1}\right)$ (Table 3) corroborated with this fact. The biocompatible (non-cytotoxic) concentration range of $\mathrm{CQ}$ from NP was selected to be used in the following experiment with HSV-1-infected cells. The positive control, acyclovir, was used in this experiment at non-cytotoxic concentration $\left(20 \mu \mathrm{g} \mathrm{mL}^{-1}\right)$.

The first-line of treatment for HSV infection consists in the use of acyclic analogue of guanosine and its derivatives. While these drugs have distinct metabolic pathways, they all act by blocking the synthesis of viral DNA, inhibiting DNA polymerase [58]. Three phosphorylation steps are required for the acyclovir action. The first phosphorylation is performed by the viral thymidine kinase (TK) encoded by the UL23 gene, while subsequent phosphorylation steps are performed by the host cell kinases [59]. Currently, there are some strains of HSV-1 resistant to acyclovir, in which the presence of mutations in UL23 and/or UL30 viral genes responsible for encoding TK and DNA polymerase, were detected [60]. The emergence of new strains resistant to conventional drugs highlight the need for new effective antiviral therapies with novel mechanisms of action [61,62]. Thus, new anti-herpetic drugs with different mechanism of action should be achieved.

In this context, this work focused on the role of $C Q$, which is a highlighted lysosomotropic drug among the molecules with proved antiviral activity [18-24,63]. The CQ has shown pronounced antiviral action against different viruses [64]. The study reported by Koyama and Uchida (1984) demonstrated that the multiplication of the HSV-1 strain HF in Vero cells was inhibited by ammonium chloride and chloroquine. It was also observed that the maturation of the intracellular virus was 
prevented immediately after the addition of weak bases in the late stage of infection, indicating that the site of inhibition by weak bases is one step in the maturation process of HSV-1 [34]. This present study showed that Vero E6 cells infected with HSV-1 and treated with CQ and CQ-NP at $30 \mu \mathrm{g} \mathrm{mL}^{-1}$ have $100 \%$ of viral replication inhibition after $48 \mathrm{~h}$ (Figure $4 \mathrm{~A}$ ). At the concentration range from 2.5 to $20 \mu \mathrm{g} \mathrm{mL}^{-1}$, the PLA NP significantly improved the anti-HSV-1 of CQ (Figure 4A). The CQ-NP induced an $\mathrm{IC}_{50}$ considerable lesser than that identified for $\mathrm{CQ}$ (Table 3). In addition, the CQ-NP (at $10 \mu \mathrm{g} \mathrm{mL}^{-1}$ and $20 \mu \mathrm{g} \mathrm{mL}^{-1}$ ) induced similar HSV-1 viral inhibition than that observed for the positive control, acyclovir, at $20 \mu \mathrm{g} \mathrm{mL}^{-1}$ (Figure $4 \mathrm{~B}$ ).

It is well reported that polymeric nanoparticles change drug bioavailability and biodistribution, reducing side effects, and improving drug efficacy [65]. Previous studies have also demonstrated that these nanoparticles are biocompatible systems, using a cell culture approach [66,67]. The mechanism of CQ action in infected cells is still not fully solved, but some studies have proposed the changes in lysosomal $\mathrm{pH}$, with inhibition of viral packaging and maturation through the trans-Golgi network [38,68]. Thus, considering the reported resistant strains of HSV-1 to acyclovir [60], CQ-loaded PLA nanoparticles system can be suggested as an interesting and promising approach against this viral infection.

\section{Conclusions}

In this study, we found that nanoprecipitation was not the best method to encapsulate the hydrophilic CQ drugs when compared to emulsification-solvent evaporation. However, as shown in our experiments, we tried different strategies and considered important parameters to improve drug loading. Biocompatible PLA nanoparticles improved the anti-HSV-1 activity of chloroquine. The data have demonstrated an efficient nanoencapsulation method, using emulsification-solvent evaporation, able to produce sub-300nm NP, with high EE\% of the hydrophilic drug, and able to induce slow CQ release. The experimental results also revealed that CQ-NP induced similar HSV-1 inhibition that observed for the first line of the anti-HSV-1 drug acyclovir. In addition, it could be suggested that PLA NP improved CQ uptake by infected Vero E6 Cell, consisting in a promising approach to solve the drug limitations to overcome biological barriers and targeting affected cells. Further studies are required to corroborate with this hypothesis using animal models or more complex tests to assess possible strategies for functionalizing NP.

Author Contributions: T.L.C.L., R.d.C.F., K.J.S.F., and A.A.d.S.-J. conceived and designed the experiments. R.d.C.F., E.d.S.-S., and E.S.T.d.E. prepared, monitored physicochemical properties of NP preparation and wrote this part. The experiments with cells and viruses were performed by T.L.C.L., E.M.d.S.S., P.R.L.M., and K.J.S.F., A.M.C., E.S.T.d.E., and M.d.F.F.-P. contributed to the discussion and revised the manuscript. K.J.S.F., and A.A.d.S.-J. wrote and refined the final version of the manuscript for publication. All authors read and approved the final manuscript.

Funding: This research was funded by Brazilian National Council for Scientific and Technological Development (CNPq) for financial support [grant numbers: 481767/2012-6, 308382/2017-0]), The Coordination for the Improvement of Higher Level (CAPES) [grant number: AUXPE no. PNPD 23038.007487/2011-91, scholarship of Tábata Loíse Cunha Lima, Emanuell dos Santos-Silva, Alaine Maria dos Santos-Silva, and Emerson Michell da Silva Siqueira].

Acknowledgments: The authors wish to thank the Pibic-CNPq Program: scholarship of Renata de Carvalho Feitosa; Silvana Maria Zucolotto Langassner (UFRN) that helped with virus HSV-1 (strain KOS) kindly provided by Cláudia Maria Oliveira Simões and Laurita Boff, from Pharmacy Faculty, Federal University of Santa Catarina, Brazil.

Conflicts of Interest: The authors declare no conflict of interest.

\section{References}

1. Li, T.; Liu, L.; Wu, H.; Chen, S.; Zhu, Q.; Gao, H.; Yu, X.; Wang, Y.; Su, W.; Yao, X.; et al. Anti-herpes simplex virus type 1 activity of Houttuynoid A, a flavonoid from Houttuynia cordata Thunb. Antivir. Res. 2017, 144, 273-280. [CrossRef] [PubMed] 
2. Li, M.; Liu, Y.; Wei, F.; Shen, M.; Zhong, Y.; Li, S.; Chen, L.; Ma, N.; Liu, B.; Mao, Y.; et al. The antiviral activity of arbidol hydrochloride against herpes simplex virus type i in vitro and in vivo. Int. J. Antimicrob. Agents 2017, 51, 96-106. [CrossRef]

3. de Oliveira, A.; Prince, D.; Lo, C.-Y.; Lee, L.H.; Chu, T.-C. Antiviral activity of theaflavin digallate against herpes simplex virus type 1. Antivir. Res. 2015, 118, 56-67. [CrossRef] [PubMed]

4. Johnson, K.E.; Chikoti, L.; Chandran, B. Herpes Simplex Virus 1 Infection Induces Activation and Subsequent Inhibition of the IFI16 and NLRP3 Inflammasomes. J. Virol. 2013, 87, 5005-5018. [CrossRef] [PubMed]

5. Terlizzi, M.E.; Occhipinti, A.L.; Maffei, A.; Massimo, E.; Gribaudo, G. Inhibition of herpes simplex type 1 and type 2 infections by Oximacro ${ }^{\circledR}$, a cranberry extract with a high content of A-type proanthocyanidins (PACs-A). Antivir. Res. 2016, 132, 154-164. [CrossRef] [PubMed]

6. Strand, M.; Islam, K.; Edlund, K.; Oberg, C.T.; Allard, A.; Bergström, T.; Mei, Y.-F.; Elofsson, M.; Wadell, G. 2-[4,5-Difluoro-2-(2-fluorobenzoylamino)-benzoylamino] benzoic acid, an antiviral compound with activity against acyclovir-resistant isolates of herpes simplex virus types 1 and 2. Antimicrob. Agents Chemother. 2012, 56, 5735-5743. [CrossRef] [PubMed]

7. Gavanji, S.; Sayedipour, S.S.; Larki, B.; Bakhtari, A. Antiviral activity of some plant oils against herpes simplex virus type 1 in Vero cell culture. J. Acute Med. 2015, 5, 62-68. [CrossRef]

8. Lopes, N.; Ray, S.; Espada, S.F.; Bomfim, W.A.; Ray, B.; Faccin-Galhardi, L.C.; Linhares, R.E.C.; Nozawa, C. Green seaweed Enteromorpha compressa (Chlorophyta, Ulvaceae) derived sulphated polysaccharides inhibit herpes simplex virus. Int. J. Biol. Macromol. 2017, 102, 605-612. [CrossRef] [PubMed]

9. Priengprom, T.; Ekalaksananan, T.; Kongyingyoes, B.; Suebsasana, S.; Aromdee, C.; Pientong, C. Synergistic effects of acyclovir and 3, 19-isopropylideneandrographolide on herpes simplex virus wild types and drug-resistant strains. BMC Complement. Altern. Med. 2015, 15, 56. [CrossRef] [PubMed]

10. Bhalekar, M.R.; Upadhaya, P.G.; Madgulkar, A.R. European Journal of Pharmaceutical Sciences Fabrication and ef fi cacy evaluation of chloroquine nanoparticles in CFA-induced arthritic rats using TNF- $\alpha$ ELISA. PHASCI 2016, 84, 1-8. [CrossRef]

11. Rainsford, K.D.; Parke, A.L.; Clifford-Rashotte, M.; Kean, W.F. Therapy and pharmacological properties of hydroxychloroquine and chloroquine in treatment of systemic lupus erythematosus, rheumatoid arthritis and related diseases. Inflammopharmacology 2015, 23, 231-269. [CrossRef] [PubMed]

12. An, N.; Chen, Y.; Wang, C.; Yang, C.; Wu, Z.H.; Xue, J.; Ye, L.; Wang, S.; Liu, H.F.; Pan, Q. Chloroquine Autophagic Inhibition Rebalances Th17/Treg-Mediated Immunity and Ameliorates Systemic Lupus Erythematosus. Cell. Physiol. Biochem. 2017, 44, 412-422. [CrossRef] [PubMed]

13. Zhang, X.; Zeng, X.; Liang, X.; Yang, Y.; Li, X. The chemotherapeutic potential of PEG- b -PLGA copolymer micelles that combine chloroquine as autophagy inhibitor and docetaxel as an anti-cancer drug. Biomaterials 2014, 35, 9144-9154. [CrossRef] [PubMed]

14. Zhang, X.; Dong, Y.; Zeng, X.; Liang, X.; Li, X.; Tao, W.; Chen, H.; Jiang, Y.; Mei, L.; Feng, S.S. The effect of autophagy inhibitors on drug delivery using biodegradable polymer nanoparticles in cancer treatment. Biomaterials 2014, 35, 1932-1943. [CrossRef] [PubMed]

15. Jia, L.; Wang, J.; Wu, T.; Wu, J.; Ling, J.; Cheng, B. In vitro and in vivo antitumor effects of chloroquine on oral squamous cell carcinoma. Mol. Med. Rep. 2017, 16, 5779-5786. [CrossRef] [PubMed]

16. Li, M.L.; Xu, Y.Z.; Lu, W.J.; Li, Y.H.; Tan, S.S.; Lin, H.J.; Wu, T.M.; Li, Y.; Wang, S.Y.; Zhao, Y.L. Chloroquine potentiates the anticancer effect of sunitinib on renal cell carcinoma by inhibiting autophagy and inducing apoptosis. Oncol. Lett. 2018, 15, 2839-2846. [CrossRef] [PubMed]

17. Fu, Z.; Xi, C.; Kuang, J.; Feng, H.; Chen, L.; Liang, J.; Shen, X.; Yuen, S.; Chenghong, P.; Baiyong, S.; et al. CQ sensitizes human pancreatic cancer cells to gemcitabine through the lysosomal apoptotic pathway via reactive oxygen species. Mol. Oncol. 2018, 12, 529-544. [CrossRef] [PubMed]

18. Keyaerts, E.; Li, S.; Vijgen, L.; Rysman, E.; Verbeeck, J.; Van Ranst, M.; Maes, P. Antiviral Activity of Chloroquine against Human Coronavirus OC43 Infection in Newborn Mice. Antimicrob. Agents Chemother. 2009, 53, 3416-3421. [CrossRef] [PubMed]

19. Juvenal, K.; Farias, S.; Renata, P.; Machado, L.; Antônio, B. Chloroquine Inhibits Dengue Virus Type 2 Replication in Vero Cells but Not in C6/36 Cells. 2013, 2013, 282734.

20. Juvenal, K.; Farias, S.; Renata, P.; Machado, L.; Pereira, A.; Muniz, C. Antiviral Activity of Chloroquine Against Dengue Virus Type 2 Replication in Aotus Monkeys. 2015, 28, 161-169. [CrossRef] 
21. Marco Isaac, B.-L.; María del Carmen, M.-G.; José Guillermo, V.-R.; Mario Enrique, R.-M.; Sergio, F.-H.; César, R.-B.; Margarito, S.-G.; Blanca Ariadna, C.-A. Effect of Tenofovir/Emtricitabine/Efavirenz with and without Chloroquine in Patients with HIV/AIDS C3: Double Blinded Randomized Clinical Trial. J. Pharmacovigil. 2015, 3. [CrossRef]

22. Long, J.; Wright, E.; Molesti, E.; Temperton, N.; Barclay, W. Antiviral therapies against Ebola and other emerging viral diseases using existing medicines that block virus entry. F1000Research 2015, 4. [CrossRef] [PubMed]

23. Delvecchio, R.; Higa, L.; Pezzuto, P.; Valadão, A.; Garcez, P.; Monteiro, F.; Loiola, E.; Dias, A.; Silva, F.; Aliota, M.; et al. Chloroquine, an Endocytosis Blocking Agent, Inhibits Zika Virus Infection in Different Cell Models. Viruses 2016, 8, 322. [CrossRef] [PubMed]

24. Khan, M.; Santhosh, S.R.; Tiwari, M.; Lakshmana Rao, P.V.; Parida, M. Assessment of in vitro prophylactic and therapeutic efficacy of chloroquine against chikungunya virus in vero cells. J. Med. Virol. 2010, 82, 817-824. [CrossRef] [PubMed]

25. Santos-Magalhães, N.S.; Mosqueira, V.C.F. Nanotechnology applied to the treatment of malaria. Adv. Drug Deliv. Rev. 2010, 62, 560-575. [CrossRef] [PubMed]

26. Pushpalatha, R.; Selvamuthukumar, S.; Kilimozhi, D. Nanocarrier mediated combination drug delivery for chemotherapy-A review. J. Drug Deliv. Sci. Technol. 2017, 39, 362-371. [CrossRef]

27. Crucho, C.I.C.; Teresa, M. Polymeric nanoparticles: A study on the preparation variables and characterization methods. Mater. Sci. Eng. C. 2017, 80, 771-784. [CrossRef] [PubMed]

28. Baruah, U.K.; Gowthamarajan, K.; Vanka, R.; Karri, V.V.S.R.; Selvaraj, K.; Jojo, G.M. Malaria treatment using novel nano-based drug delivery systems. J. Drug Target. 2017, 25, 567-581. [CrossRef] [PubMed]

29. Mishra, B.; Patel, B.B.; Tiwari, S. Colloidal nanocarriers: A review on formulation technology, types and applications toward targeted drug delivery. Nanomedicine 2010, 6, 9-24. [CrossRef] [PubMed]

30. Vrignaud, S.; Benoit, J.P.; Saulnier, P. Strategies for the nanoencapsulation of hydrophilic molecules in polymer-based nanoparticles. Biomaterials 2011, 32, 8593-8604. [CrossRef] [PubMed]

31. Dalpiaz, A.; Sacchetti, F.; Baldisserotto, A.; Pavan, B.; Maretti, E.; Iannuccelli, V.; Leo, E. Application of the "in-oil nanoprecipitation" method in the encapsulation of hydrophilic drugs in PLGA nanoparticles. J. Drug Deliv. Sci. Technol. 2016, 32, 283-290. [CrossRef]

32. Miladi, K.; Sfar, S.; Fessi, H.; Elaissari, A. Encapsulation of alendronate sodium by nanoprecipitation and double emulsion: From preparation to in vitro studies. Ind. Crops Prod. 2015, 72, 24-33. [CrossRef]

33. Peltonen, L.; Aitta, J.; Hyvönen, S.; Karjalainen, M.; Hirvonen, J. Improved entrapment efficiency of hydrophilic drug substance for nanoprecipitation of poly(l)lactide nanoparticles. AAPS PharmSciTech 2004, 5, 16. [CrossRef]

34. Koyama, A.H.; Uchida, T. Inhibition of multiplication of herpes simplex virus type 1 by ammonium chloride and chloroquine. Virology 1984, 138, 332-335. [CrossRef]

35. Lebon, P. Inhibition of Herpes Simplex Virus Type 1-induced Interferon Synthesis by Monoclonal Antibodies against Viral Glycoprotein D and by Lysosomotropic Drugs. J. Gen. Virol. 1985, 66, 2781-2786. [CrossRef] [PubMed]

36. Harley, C.A.; Dasgupta, A.; Wilson, D.W. Characterization of herpes simplex virus-containing organelles by subcellular fractionation: role for organelle acidification in assembly of infectious particles. J. Virol. 2001, 75, 1236-1251. [CrossRef] [PubMed]

37. McClain, L.; Zhi, Y.; Cheng, H.; Ghosh, A.; Piazza, P.; Yee, M.B.; Kumar, S.; Milosevic, J.; Bloom, D.C.; Arav-Boger, R.; et al. Broad-spectrum non-nucleoside inhibitors of human herpesviruses. Antivir. Res. 2015, 121, 16-23. [CrossRef] [PubMed]

38. Singh, A.K.; Sidhu, G.S.; Friedman, R.M.; Maheshwari, R.K. Mechanism of Enhancement of the Antiviral Action of Interferon Against Herpes Simplex Virus-1 by Chloroquine. J. Interf. Cytokine Res. 1996, 16, 725-731. [CrossRef] [PubMed]

39. Fessi, H.; Puisieux, F.; Devissaguet, J.P.; Ammoury, N.; Benita, S. Nanocapsule formation by interfacial polymer deposition following solvent displacement. Int. J. Pharm. 1989, 55, 1-4. [CrossRef]

40. Souto, E.B.; Severino, P.; Santana, M.H.A. Preparation of Polymeric Nanoparticles from Pre-Formed Polymers-Part II. Polímeros 2012, 22, 101-106. [CrossRef] 
41. Caldas dos Santos, T.; Rescignano, N.; Boff, L.; Reginatto, F.H.; Simões, C.M.O.; de Campos, A.M.; Mijangos, C. In vitro antiherpes effect of C-glycosyl flavonoid enriched fraction of Cecropia glaziovii encapsulated in PLGA nanoparticles. Mater. Sci. Eng. C 2017, 75, 1214-1220. [CrossRef] [PubMed]

42. Baram-Pinto, D.; Shukla, S.; Perkas, N.; Gedanken, A.; Sarid, R. Inhibition of Herpes Simplex Virus Type 1 Infection by Silver Nanoparticles Capped with Mercaptoethane Sulfonate. Bioconjug. Chem. 2009, 20, 1497-1502. [CrossRef] [PubMed]

43. dos Santos-Silva, A.M.; de Caland, L.B.; de SL Oliveira, A.L.C.; de Araújo-Júnior, R.F.; Fernandes-Pedrosa, M.F.; Cornélio, A.M.; da Silva-Júnior, A.A. Designing structural features of novel benznidazole-loaded cationic nanoparticles for inducing slow drug release and improvement of biological efficacy. Mater. Sci. Eng. C 2017, 78, 978-987. [CrossRef] [PubMed]

44. de Oliveira, A.R.; Mesquita, P.C.; Machado, P.R.L.; Farias, K.J.S.; de Almeida, Y.M.B.; Fernandes-Pedrosa, M.F.; Cornélio, A.M.; do Egito, E.S.T.; da Silva-Júnior, A.A. Monitoring structural features, biocompatibility and biological efficacy of gamma-irradiated methotrexate-loaded spray-dried microparticles. Mater. Sci. Eng. C 2017, 80, 438-448. [CrossRef] [PubMed]

45. Pujol, C.A.; Sepúlveda, C.S.; Richmond, V.; Maier, M.S.; Damonte, E.B. Polyhydroxylated sulfated steroids derived from $5 \alpha$-cholestanes as antiviral agents against herpes simplex virus. Arch. Virol. 2016, 161, 1993-1999. [CrossRef] [PubMed]

46. Bisignano, C.; Mandalari, G.; Smeriglio, A.; Trombetta, D.; Pizzo, M.; Pennisi, R.; Sciortino, M. Almond Skin Extracts Abrogate HSV-1 Replication by Blocking Virus Binding to the Cell. Viruses 2017, 9, 178. [CrossRef] [PubMed]

47. Biswal, I.; Dinda, A.; Mohanty, S.; Dhara, M.; Das, D.; Chowdary, K.A.; Si, S. Influence of drug/polymer ratio on the encapsulation efficiency of highly hydrophilic drug. Asian J. Chem. 2011, 23, 1973-1978.

48. Halayqa, M.; Domańska, U. PLGA biodegradable nanoparticles containing perphenazine or chlorpromazine hydrochloride: Effect of formulation and release. Int. J. Mol. Sci. 2014, 15, 23909-23923. [CrossRef] [PubMed]

49. Cheow, W.S.; Hadinoto, K. Colloids and Surfaces A: Physicochemical and Engineering Aspects Enhancing encapsulation efficiency of highly water-soluble antibiotic in poly(lactic-co-glycolic acid) nanoparticles: Modifications of standard nanoparticle preparation methods. Colloids Surfaces A Physicochem. Eng. Asp. 2010, 370, 79-86. [CrossRef]

50. Rivas-Granizo, P.; Santos, S.R.C.J.; Ferraz, H.G. Development of a Stability-Indicating LC Assay Method for Determination of Chloroquine. Chromatogr. Suppl. 2009, 69, 137-141. [CrossRef]

51. Maruyama, A.; Ishihara, T.; Kim, J.S.; Kim, S.W.; Akaike, T. Nanoparticle DNA carrier with poly(L-lysine) grafted polysaccharide copolymer and poly(D,L-lactic acid). Bioconjug. Chem. 1997, 8, 735-742. [CrossRef] [PubMed]

52. Wu, L.; Zhang, J.; Watanabe, W. Physical and chemical stability of drug nanoparticles. Adv. Drug Deliv. Rev. 2011, 63, 456-469. [CrossRef] [PubMed]

53. Hoo, C.M.; Starostin, N.; West, P.; Mecartney, M.L. A comparison of atomic force microscopy (AFM) and dynamic light scattering (DLS) methods to characterize nanoparticle size distributions. J. Nanopart. Res. 2008, 10, 89-96. [CrossRef]

54. Roopkishora; Singh, A.; Singh, C.L. Development and Characterization of Hydroxyl Chloroquine Sulphate. Int. J. Pharm. Sci. Drug Res. 2015, 7, 22-26.

55. Magalhães, G.A., Jr.; Moura Neto, E.; Sombra, V.G.; Richter, A.R.; Abreu, C.M.W.S.; Feitosa, J.P.A.; Paula, H.C.B.; Goycoolea, F.M.; de Paula, R.C.M. Chitosan/Sterculia striata polysaccharides nanocomplex as a potential chloroquine drug release device. Int. J. Biol. Macromol. 2016, 88, 244-253. [CrossRef] [PubMed]

56. Kang, T.; Zhu, Q.; Jiang, D.; Feng, X.; Feng, J.; Jiang, T.; Yao, J.; Jing, Y.; Song, Q.; Jiang, X.; et al. Synergistic targeting tenascin $C$ and neuropilin-1 for specific penetration of nanoparticles for anti-glioblastoma treatment. Biomaterials 2016, 101, 60-75. [CrossRef] [PubMed]

57. Lin, J.; Zhang, H.; Chen, Z.; Zheng, Y. Penetration of lipid membranes by gold nanoparticles: Insights into cellular uptake, cytotoxicity, and their relationship. ACS Nano 2010, 4, 5421-5429. [CrossRef] [PubMed]

58. James, S.H.; Prichard, M.N. Current and future therapies for herpes simplex virus infections: mechanism of action and drug resistance. Curr. Opin. Virol. 2014, 8, 54-61. [CrossRef] [PubMed]

59. Burrel, S.; Bonnafous, P.; Hubacek, P.; Agut, H.; Boutolleau, D. Impact of novel mutations of herpes simplex virus 1 and 2 thymidine kinases on acyclovir phosphorylation activity. Antivir. Res. 2012, 96, 386-390. [CrossRef] [PubMed] 
60. Piret, J.; Boivin, G. Antiviral drug resistance in herpesviruses other than cytomegalovirus. Rev. Med. Virol. 2014, 24, 186-218. [CrossRef] [PubMed]

61. Piret, J.; Boivin, G. Resistance of Herpes Simplex Viruses to Nucleoside Analogues: Mechanisms, Prevalence, and Management. Antimicrob. Agents Chemother. 2011, 55, 459-472. [CrossRef] [PubMed]

62. Andrei, G.; Snoeck, R. Herpes simplex virus drug-resistance. Curr. Opin. Infect. Dis. 2013, 26, 551-560. [CrossRef] [PubMed]

63. Savarino, A.; Di Trani, L.; Donatelli, I.; Cauda, R.; Cassone, A. New insights into the antiviral effects of chloroquine. Lancet Infect. Dis. 2006, 6, 67-69. [CrossRef]

64. Inglot, A.D. Comparison of the Antiviral Activity in vitro of some Non-steroidal Anti-inflammatory Drugs. J. Gen. Virol. 1969, 4, 203-214. [CrossRef] [PubMed]

65. Cavalli, R.; Donalisio, M.; Civra, A.; Ferruti, P.; Ranucci, E.; Trotta, F.; Lembo, D. Enhanced antiviral activity of Acyclovir loaded into $\beta$-cyclodextrin-poly(4-acryloylmorpholine) conjugate nanoparticles. J. Control. Release 2009, 137, 116-122. [CrossRef] [PubMed]

66. Mesquita, P.C.; Silva, E.S.; Streck, L.; Damasceno, I.Z.; Maia, A.M.S.; Fernandes-Pedrosa, M.F.; Silva-Júnio, A.A. Cationic functionalized biocompatible polylactide nanoparticles for slow release of proteins. Colloids Surfaces A Physicochem. Eng. Asp. 2017, 513, 442-451. [CrossRef]

67. Wurm, M.C.; Möst, T.; Bergauer, B.; Rietzel, D.; Neukam, F.W.; Cifuentes, S.C.; von Wilmowsky, C. In Vitro evaluation of Polylactic acid (PLA) manufactured by fused deposition modeling. J. Biol. Eng. 2017, 11, 29. [CrossRef] [PubMed]

68. Shah, A.; Farooq, A.V.; Tiwari, V.; Kim, M.-J.; Shukla, D. HSV-1 infection of human corneal epithelial cells: receptor-mediated entry and trends of re-infection. Mol. Vis. 2010, 16, 2476-2486. [PubMed]

(C) 2018 by the authors. Licensee MDPI, Basel, Switzerland. This article is an open access article distributed under the terms and conditions of the Creative Commons Attribution (CC BY) license (http://creativecommons.org/licenses/by/4.0/). 